\title{
LASTEN JA NUORTEN AIKUISTEN KOKEMUKSIA VUOROASUMISEEN LIITTYVÄSTÄ PÄÄTÖKSENTEOSTA
}

Hannariikka Linnavuori: KT, Iyväskylän yliopisto

Elina Stenvall: VTT, kehittämissunnittelija, SOS-Lapsikylä/Tampereen yliopisto

hannariikka.linnavuori@gmail.com; elina.stenvall@gmail.com

(J)

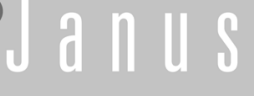

Janus vol. 28 (1) 2020, 3-19

Tiivistelmä

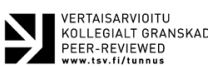

Artikkeli keskittyy lasten kokemuksiin ja osallisuuteen vuoroasumiseen liittyvässä päätöksenteossa. Laadullinen pitkittäisaineisto koostuu vuoroasuvien lasten ja samoille henkilöille nuorina aikuisina tehdyistä haastatteluista. Teoreettisena lähtökohtana on John Agnew'n (2002) ajattelu ihmisen päätöksentekoon samanaikaisesti vaikuttavista yksilöllisistä ja yhteisöllisistä motiiveista.Vuoroasuminen näyttäytyi moninaisena ja muuttuvana järjestelynä. Haastatellut kokivat olleensa mukana vaikuttamassa vuoroasumista koskevassa päätöksenteossa, vaikka vanhemmat olivatkin useimmiten päättäneet asumisen periaatteesta. He pitivät tärkeänä, että lapset saavat halutessaan osallistua päätöksentekoon ja että aikuiset ottavat lasten mielipiteet huomioon. Toisaalta on muistettava, että aikuiset kantavat vastuun päätöksistä.Vuoroasumisen voi olla paras ratkaisu eron jälkeisiin asumisjärjestelyihin, mikäli se toteutetaan lapsilähtöisesti, mutta se voi olla huonoin ratkaisu, jos lapsen mielipide ohitetaan. Jokaisen perheen ja lapsen tilanne on yksilöllinen, joten myös ratkaisujen on oltava yksilöllisiä.

\section{JOHDANTO: MitÄ TIEDETÄÄN VUOROASUMISESTA?}

Vuoroasuminen tarkoittaa asumismuotoa, jossa lapset asuvat erotilanteen jälkeen vuorotellen ja lähes yhtä pitkiä aikoja molempien vanhempiensa luona (Linnavuori 2007, 10; Oikeusministeriö 2017,30). Käytännössä vuoroasumisessa on kyse jaetusta huollosta, vaikka se ei virallisena huoltomuotona ole vuoroasumisen edellytys. Ruotsalaislasten vuoroasumista tutkineen Jani Turusen (2016) mukaan vuoroasuminen takaa yhteyden molempiin vanhempiin ja vähentää lasten kokemaa stressiä. Myös Linda Nielsen (2014) on todennut, että vuoroasuvat lapset kokevat hyvinvointinsa paremmaksi kuin yksinhuoltajaperheissä asuvat. Sekä Turunen että
Nielsen katsovat paremman hyvinvoinnin johtuvan vanhempien jakamasta vastuusta ja vuoroasumisen takaamasta vanhemmuuden tuesta. Nielsen (2018) toteaa uudessa meta-analyysissään, että vuoroasumisen hyödyt eivät häviä, vaikka vanhemmat riitelisivät. Samankaltaisiin tuloksiin on päädytty myös Suomessa vuoden 2015 nuorisobarometrissä (Myllyniemi 2015), Helsingin kaupungin lasten ja nuorten hyvinvointia ja arkea selvittäneessä tutkimuksessa (Stenvall 2009) ja nuorten riskikäyttäytymistä ja hyvinvointia kartoittaneessa tutkimuksessa (Rissanen 2016). Näiden tutkimusten valossa näyttää siltä, että vuoroasuvat lapset vertautuvat monilla hyvinvoinnin osa-alueilla ydinperheissä eläviin lapsiin. 
Joidenkin tutkimusten mukaan vanhempien riidat vaikuttavat kielteisesti lasten kokemukseen vuoroasumisesta (Cashmore ym. 2010, 133; McIntosh ym. 2010). Toinen ristiriitainen aihe on kiintymyssuhteen rakentumiseen liittyvä pienten lasten vuoroasuminen (esim. Forsberg ym. 2014). Kärjistäen voisi kysyä, hyötyykö lapsi suhteesta kumpaankin vanhempaan enemmän kuin hän kärsii erossa olosta äidistä? Tutkimusnäytöstä osa puoltaa yhtä kotia pikkulapsille (esim. McIntosh ym. 2010), samalla kun osa kannattaa vuoroasumista, mutta tiheällä vaihtovälillä (esim. Lamb \& Kelly 2009). Ruotsalaistutkijat ovat todenneet, että pikkulasten (0-3v) hyvinvointi riippuu enemmän vanhempien yhteistyökyvystä, riitojen määrästä ja herkkyydestä lapsen tarpeille kuin siitä, missä lapset asuvat ja nukkuvat (Fransson, Bergström \& Hjern 2015).

Myös suomalainen tutkimus vuoroasumisesta on lisääntynyt viime vuosina (Linnavuori 2007; Keskinen ja Högnabba 2014; Autonen-Vaaraniemi \& Forsberg 2015; Forsberg ym. 2014; Sarasoja \& Rantala 2015; Rissanen 2016; Rissanen ym. 2017) ja termi on löytänyt tiensä myös laajempaan yhteiskunnalliseen keskusteluun (esim. HS 30.4.2015; YLE 23.10.2015; MTV 13.11.2016; HS 11.2.2017). Ruotsissa vuoroasumista on tutkittu pidempään (esim. Öberg \& Öberg 1985; 2002; Carlsund ym. 2012; Bergström ym. 2013; Turunen 2016) ja vuoroasuminen on yleinen tapa järjestää lasten asuminen eron jälkeen (Demografiska rapporter 2014). Myös tuomioistuimella on Ruotsissa mahdollisuus määrätä perhe valitsemaan vuoroasuminen lasten asumismuodoksi, vaikka toinen vanhempi sitä vastustaisi (Rissanen 2016). Lisäksi esimerkiksi Belgiassa (Sodermans ym. 2013) ja Australiassa (Campo ym. 2012) juridisena lähtökohtana on vuodesta 2006 alkaen ollut jaettu vanhemmuus eli käytännössä vuoroasuminen, mikäli se ei jostain syystä ole lapsen edun vastaista.

Vuoroasuminen ei ole Suomessa ollut virallinen perhemuoto, joten tilastoinnin ja väestölaskennan tavat eivät ole kyenneet sitä tunnistamaan (Forsberg ym. 2014; Autonen-Vaaraniemi \& Forsberg 2015). Tilastoinnin hankaluus johtuu osittain myös lainsäädännöstä: lapsella voi toistaiseksi Suomessa olla vain yksi osoite ja hän voi näin ollen olla kirjattuna vain yhteen asuinpaikkaan. Tämä epäkohta on jo tiedostettu, ja jos lapsenhuoltolain uudistaminen etenee työryhmämietinnön mukaisesti, voidaan vuoroasuva lapsi jatkossa merkitä väestötietojärjestelmässä kahteen osoitteeseen (Oikeusministeriö 2017). Hallinnolliseen epäkohtaan on alettu kiinnittää huomiota myös muualla, ja esimerkiksi Terveyden ja hyvinvoinnin laitos (THL) on alkanut vuodesta 2009 määritellä kyselyissään vuoroasumisen yhdeksi perhemuodon vaihtoehdoksi (Sarasoja \& Rantala 2015). Näiden THL:n tilastojen avulla voidaan valottaa niiden vuoroasuvien lasten määrää, joiden asumisesta on sovittu lastenvalvojan luona: Suomessa on 2010-luvulla tehty vuosittain noin 2600 sopimusta, jossa lapsi asuu vuorotellen molempien vanhempien luona. Näiden sopimusten määrä lisääntyi reilusti 2017, jolloin niitä tehtiin yli 3100. Kaikista sopimuksista tämä on noin 18 prosenttia (Forss ja Säkkinen 2018).Vuoroasumista voidaan kuitenkin toteuttaa myös ilman sosiaalitoimessa laadittua sopimusta. 


\section{TUtKIMUKSEN AINEISTO JA TAVOITTEET}

Tässä artikkelissa analysoimme lasten ja nuorten aikuisten kokemuksia ja käsityksiä lapsuuden vuoroasumiseen liittyvästä päätöksenteosta Hannariikka Linnavuoren pitkittäisaineistoa hyödyntäen. Tämä aineisto muodostaa ensimmäisen Suomessa kerätyn vuoroasumiseen keskittyvän pitkittäisaineiston. Pitkittäistutkimukset lasten vuoroasumiseen liittyen ovat harvinaisia myös kansainvälisesti (ks. Kaltenborn 2001; Öberg \& Öberg 2002).

Aineisto käsittää 20 haastattelua 8-18-vuotiailta vuoroasuvilta lapsilta vuodelta 2005 sekä 16 haastattelua samoilta ihmisiltä 19-29-vuotiaina vuodelta 2016. Aineistoesimerkeissä käytämme ensimmäisestä haastattelusta nimitystä lapsena tehty haastattelu (lth) ja jälkimmäisestä aikuisena tehty haastattelu (ath). Haastateltavat lapset (12 tyttöä ja 8 poikaa) tavoitettiin vuonna 2005 kahden eteläsuomalaisen kaupungin sosiaalitoimistoissa laadittujen tapaamissopimusten perusteella. Haastatteluun pyydettiin molempien vanhempien lupa sekä lapsen suostumus. Mukaan valikoitui monenlaisia vanhempia: riiteleviä vanhempia, sopuisia vanhempia sekä vanhempia, jotka eivät olleet lainkaan tekemisissä toistensa kanssa. Haastatteluun osallistuneita sisaruksia oli neljästä perheestä. Aikuisena tehtyyn uuteen haastatteluun lupautui kymmenen naista ja kuusi miestä. Haastattelut kestivät ensimmäisellä haastattelukerralla keskimäärin tunnin, jälkimmäisellä puolitoista tuntia. Teemahaastattelurunko ja kysymykset olivat pääosin samoja molemmilla haastattelukerroilla. $\mathrm{Ne}$ keskittyivät asumisen käytännön järjestelyihin, päätöksentekoon, vanhempien yhteistyöhön, vuoroasumisen etuja ja haittoja kartoittaviin kysymyksiin sekä perhesuhteita avaaviin kysymyksiin. Tämän artikkelin analyysi painottuu aikuisten haastatteluihin, joissa he puhuvat paljon lapsuuden kokemuksistaan, mutta mukana analyysissä on myös lapsilta kerätty haastatteluaineisto.

Tavoitteemme on tuoda esille lapsena vuoroasuneiden haastateltujen kokemuksia vuoroasumiseen liittyvästä päätöksenteosta sekä lapsina että nuorina aikuisina. Etsimme vastauksia kysymyksiin, miksi asumismuodoksi valikoitui vuoroasuminen, millaisia muutoksia asumisessa tapahtui ja miksi, mikä oli lasten rooli asumista koskevassa päätöksenteossa sekä mikä sen haastateltujen mielestä pitäisi olla. Lisäksi tarkastelemme edellä mainituissa kysymyksissä lasten ja nuorten aikuisten näkemysten eroja ja yhtäläisyyksiä.

\section{TUTKIMUKSEN LÄHTÖKOHDAT}

Laadullinen pitkittäistutkimus valaisee kokemusten ajallista ulottuvuutta, elämän käännekohtien ja muutosten kokemista uudelleenjäsentämällä niitä nykypäivän perspektiivistä. Menneisyyden kokemukset ja tulevaisuuden ennakointi ovat tärkeitä nykyisen elämäntilanteen ymmärtämiseksi (Henwood \& Shirani 2012). Laadullista pitkittäistutkimusta on käytetty erityisesti ihmisten toiminnan, valintojen, ratkaisujen ja muutokselle annettujen henkilökohtaisten merkitysten tarkasteluun. Sitä voidaan kutsua myös laadulliseksi seurantatutkimukseksi, koska sen tyypillinen menetelmä on ihmisten seuranta havainnoiden tai uusintahaas- 
tatteluin. (Nikander 2014.) Valotamme lasten ja nuorten aikuisten kokemuksia vuoroasumisen päätöksenteosta kahdessa eri ikävaiheessa annettujen merkitysten kautta. Artikkelia varten olemme haastatteluista poimineet lainauksia havainnollistamaan kokemuksia päätöksenteosta. Niistä olemme poistaneet tai muuttaneet tunnistamisen mahdollistavat tiedot.

Tutkimuksemme nojaa fenomenologishermeneuttiseen tutkimusperinteeseen ja tutkimusmenetelmänä olemme käyttäneet sisällönanalyysia. Tarkoitamme sisällönanalyysillä pyrkimystä kuvata haastatteluaineiston sisältöä ja ihmisten sanoittamia kokemuksia fenomenologisesti orientoituneessa tutkimuksessa (Tuomi \& Sarajärvi 2002, 13, 107). Analysoimme litteroituja haastatteluja kuvauksena henkilöiden omakohtaisesta koetusta maailmasta (Perttula 2000), tässä tapauksessa lapsuuden vuoroasumisesta ja sitä koskevasta päätöksenteosta. Teemahaastattelun runkoa käytimme aineiston teemoittelun pohjana. Aineistolähtöinen analyysi on tarpeellista erityisesti silloin, kun tarvitaan perustietoa jonkin ilmiön olemuksesta (Eskola \& Suoranta 1998, 19).

Tarkastelumme taustalla on uuden lapsuudentutkimuksen ajatus lasten osallisuuden ja toimijuuden vahvistamisesta (esim. Alanen ja Karila 2009). Vaikuttamiskokemukset ovat merkityksellisiä lasten hyvinvoinnille, sillä lapset rakentavat käsitystä itsestään suhteessa niihin kokemuksiin, joita heille muodostuu (Kallio ja Häkli 2011). Kokemukset itselle tärkeisiin asioihin vaikuttamisesta muokkaavat myös käsitystä itselle olemassa olevista mahdollisuuksista (Stenvall 2018). Tämä tulee näkyviin esimerkiksi tilanteissa, joissa määritellään, otetaanko lapsen näkemys huomioon asioista päätettäessä tai kokeeko lapsi mahdolliseksi tuoda oman mielipiteensä julki. Lapset haluavat osallistua asumistaan koskevaan päätöksentekoon (Socialstyrelsen 2004). Lisäksi mahdollisuus olla mukana päättämässä asioista auttaa lapsia hyväksymään tehdyt päätökset ja sopeutumaan niihin sekä lisää tyytyväisyyttä järjestelyihin yleisesti (Smith ym. 2003; Parkinson ym. 2005).

Lasten osallistumista päätöksentekoon on arvioitava myös yksilöllisesti. YK:n yleissopimus lasten oikeuksista (1989) edellyttää, että lapsella on oikeus ilmaista näkemyksensä kaikissa häntä koskevissa asioissa, mutta mahdollisuus päätöksentekoon tulee suhteuttaa lapsen ikään. Lasten oikeus olla mukana ei tarkoita automaattisesti lapsen mielipiteen mukaan toimimista tai muiden näkökulmien sivuuttamista, vaan tarkoituksena on tunnistaa lasten mukanaolon merkitys kussakin tilanteessa tarkoituksenmukaisesti, jotta kestäviä päätöksiä voidaan tehdä.

Teoreettisesti tukeudumme John Agnew'n (2002) ajatteluun, jonka mukaan ihminen pyrkii toiminnallaan tilanteeseen, joka on paras valittavissa oleva vaihtoehto niiden reunaehtojen puitteissa, joissa ihminen kussakin hetkessä joutuu toimimaan. Kokemuksellisesti toiminnan motiivi voi syntyä omasta itsestä käsin, jolloin ihminen pyrkii toimimaan, kuten itse kokee hyväksi. Toiminnan motiivi voi kuitenkin syntyä myös yhteisöstä käsin, jolloin ihminen pyrkii toimimaan siten, kuten olettaa toisten haluavan hänen toimia. Esimerkiksi lapset saattavat sanoa, mitä 
he olettavat vanhempien toivovan tai mitä vanhemmat ovat käskeneet sanoa, vaikka haluaisivat itse toimia toisin (Warshak 2003). Agnew'n (2002) mukaan kahtalaisuus tulee näkyviin tavoissa, joilla yksilöt ovat suhteissa toisiinsa. Vuoroasumista tarkasteltaessa tämä tarkoittaa esimerkiksi tapoja, joilla perheenjäsenet liittyvät toisiinsa, vaikka käytännön elämän järjestelyt muuttuisivat. Näissä tilanteissa lasten on kyettävä toimimaan sekä itselleen että muille perheenjäsenille hyväksyttävällä tavalla. Agnew on kuvannut, miten ihmisen käsitys omasta paikasta yhteisöissä syntyy jo lapsuudessa, mutta se elää ja muuttuu läpi koko elämän. Tähän ajatukseen tukeutuen tarkastelumme keskiössä on ajatus tunnistaa lapset samaan aikaan sekä yksilöinä että yhteisöjensä jäseninä ja jäsentää tämän erottelun avulla lasten päätöksenteon motiiveja.

\section{VUOROASUMISEEN PÄÄTYMINEN}

Haastateltujen lasten kokemusten mukaan vanhemmat olivat olleet yksimielisiä eron jälkeisestä asumisesta, jotta lapsilla säilyisi suhde kumpaankin vanhempaan. Ajatus suhteiden säilymisestä on tunnistettu vuoroasumisen motiiviksi vanhempien näkökulmasta myös muualla (esim. Panttila 2005). Tärkeimmäksi lasten esiin nostamaksi syyksi vuoroasumiseen on puolestaan tunnistettu tasapuolisuus vanhempien tapaamisessa (Öberg \& Öberg 1985; Fabricius \& Hall 2000; Singer 2008; Lodge \& Aleksander 2010; Haugen 2010; Campo ym. 2012). Nämä näkökulmat kiertyvät yhteen. Haastateltujen lasten näkökulmasta vuoroasumisen paras puoli oli se, että saa tavata molempia vanhempia yhtä paljon. Aikuisina noin puolet haastatelluista koki vuoroasumisen olleen hyvä ratkaisu, koska suhde molempiin vanhempiin säilyi. Lapset ja aikuiset näyttävät puhuvan samasta ilmiöstä, mutta hieman eri sanoin. Lisäksi sekä lasten että aikuisten haastatteluissa vuoroasumista pidettiin usein itsestään selvänä valintana: Kai se oli lähinnä sitä varten, et ois niiku molemmat vanhemmat kumminkin. Et helposti toisilla on molemmat vanhemmat, mut ei ees tunne periaatteessa sitä toista vanhemmista (Toni ath).

Lasten haastattelukerralla korostui vuoroasumisen valinta sekä lapsen että vanhempien parhaaksi. Minnan (lth) mielestä vuoroasumiseen päädyttiin siksi, että valinnan tekeminen vanhempien välillä olisi julmaa sekä niille [vanhemmille] että itellee [lapselle].Vaikka lapset olisivat kokeneet, että vuoroasuminen olisi ollut ensisijaisesti vanhempien toive, he olivat samaan aikaan sitä mieltä, että myös heidän toiveensa otettiin huomioon.Vuoroasumisesta hyvin itsenäisesti päätöksen tehnyt Minna (ath) kuvaa, miten vanhemmat olivat hänen valintansa hyväksyessään ottaneet huomioon myös toisensa; kun ajattelivat, et toinenkin haluu minua nähä, et siin kohtaa ajattelivat toisiaankin. Vaikka vuoroasuminen olisi ollut vaikeaa ja loppunut lyhyeen, pitivät haastateltavat sekä lapsina että aikuisina vanhempien perusteita siihen silti varsin epäitsekkäinä ja lapsilähtöisinä: Mun parhaaks (Aapo lth). Ajateltu lasten kannalta, että saa olla molemmissa kodeissa ja kummankin vanhemman kanssa paljon (Kata ath). Hyvien ja onnistuneiden kokemusten lisäksi haastateltavat kertoivat myös epäonnistuneiden vuoroasumiskokeilujen olleen alun perin perheenjäsenten yhteisesti sopimia. Käytännössä tämä tarkoitti 
useimmiten sitä, että vanhemmat olivat sopineet asumisen periaatteesta ja lapset vaikuttivat käytännön yksityiskohtiin, kuten vaihtovälin pituuteen. Suurin osa lapsista koki lapsuuden haastatteluissa, että heidän oli ollut jollain tavalla mahdollista vaikuttaa asumisensa järjestämiseen.

\section{AsUMisJÄRJESTELYJEN MUUTOKSET JA NIIDEN MOTIIVIT}

Kuviossa 1 tarkastelemme asumisjärjestelyjen vaihtuvuutta lasten iän myötä. Kuvion avulla tulee näkyväksi, miten haastateltujen lasten asuminen on muotoutunut sekä heidän ikänsä että erosta kuluneen ajan myötä. Kuviossa ydinperhe tarkoittaa aikaa ennen vanhempien eroa. Vanhempien erotessa haastatellut lapset olivat 5-14-vuotiaita. Kaikki olivat aloittaneet vuoroasumisen käytännössä saman tien. Vuoroasumisen loppuessa he olivat 12-21-vuotiaita, keskimääräinen ikä oli 16 vuotta. Itsenäinen asuminen aloitettiin keskimäärin 19-vuotiaana. Neljä nuorta aikuista oli palannut väliaikaisesti asumaan takaisin äidin luo asuttuaan sitä ennen itsenäisesti.

Kuten kuviosta 1 voidaan todeta, kaikkiaan kuusi haastateltavaa oli vuoroasunut koko ajan vanhempien erosta aina itsenäiseen asumiseen saakka. Kahdeksan asui lopuksi enemmän tai ainoastaan äidillä, ja kaksi puolestaan isällä. Neljän kohdalla vuoroasuminen loppui toisen vanhemman muuttaessa niin kauas, ettei vuoroasuminen ollut enää järkevää. Näissä tilanteissa lapset olivat

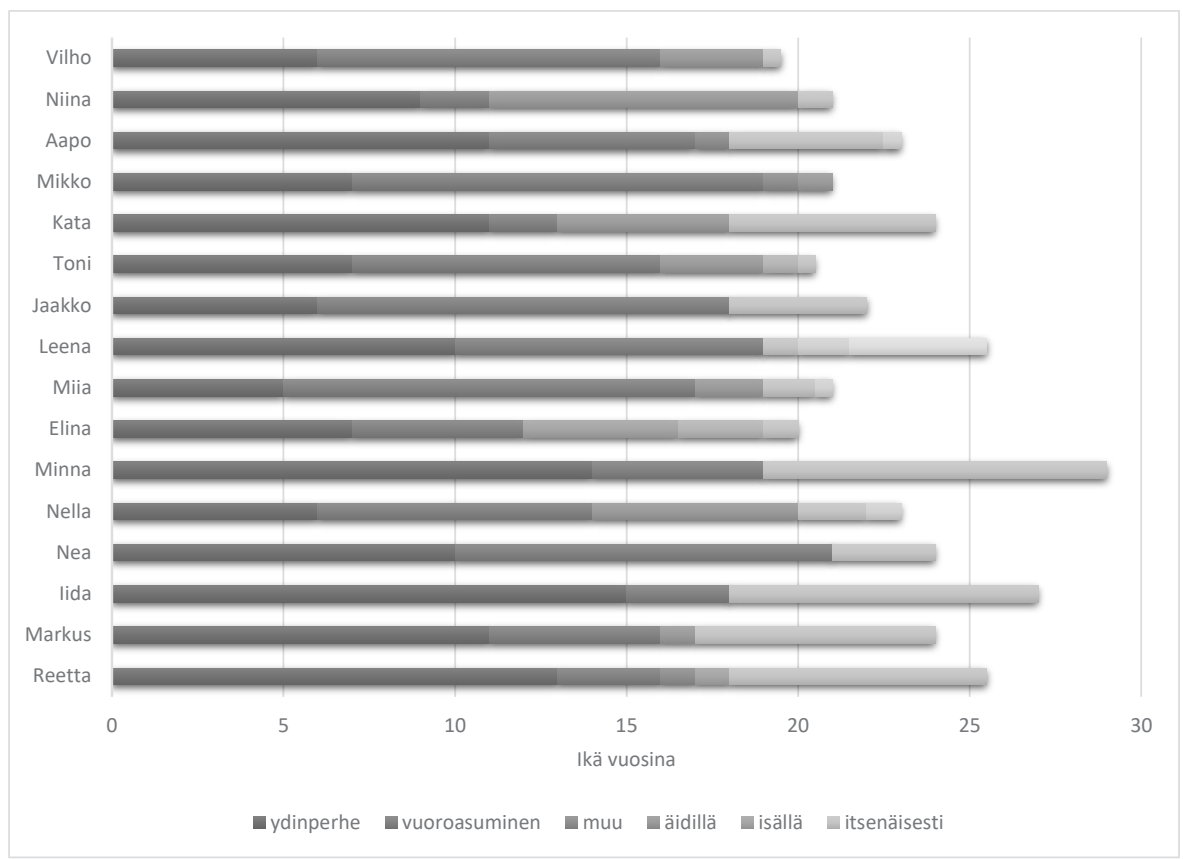

Kuvio 1. Haastateltavien asumismuoto eri ikäisenä 
iältään vähintään 16-vuotiaita. Kukaan näistä neljästä ei kertonut kokeneensa vanhemman muuttamista ja siitä aiheutunutta asumisjärjestelyn muutosta harmillisena. Pikemminkin he pitivät sitä elämään kuuluvana luonnollisena muutoksena. Tähän varmasti vaikutti myös heidän ikänsä; vuoroasuminen olisi loppunut ja itsenäinen asuminen alkanut lähiaikoina joka tapauksessa.

Agnew'n (2002) ajatteluun tukeutuen lapsuuden vuoroasumiseen liittyvät päätöksentekokokemukset saavat uudenlaisia sävyjä tarkasteltaessa niitä aikuisuudesta käsin. Esimerkiksi Elina (ath) kertoi, että päätti 12-vuotiaana muuttaa asumaan pelkästään isälle vuoroasuttuaan sitä ennen viisi vuotta. Elina kertoi tämän johtuneen siitä, että hän riiteli paljon äitinsä kanssa ja toisaalta koki itsensä samankaltaiseksi isänsä kanssa. Isällä oli myös enemmän aikaa hänelle. Vaikka äiti oli, Elinan kuvauksen mukaan, aluksi ollut muutoksesta surullinen, hän oli myöntänyt myöhemmin ratkaisun olleen oikea. Lisäksi äidin ja Elinan suhde parani, kun he eivät enää asuneet yhdessä. Vilho (ath) puolestaan muutti 16-vuotiaana asumaan pelkästään äidille, omien sanojensa mukaan ovet paukkuen, saatuaan tarpeekseen äitipuolensa käytöksestä, eikä hän enää tämän jälkeen käynyt isänsä luona. Vaikka vuoroasuttuja vuosia oli takana kymmenen, hän tapasi tämän jälkeen isäänsä useimmiten kaupungilla.

Esimerkit paljastavat osaltaan, miten lapsilla on ollut mahdollisuus tehdä omaa asumistaan koskevia ratkaisua vielä pitkään jatkuneen vuoroasumisen jälkeenkin. Tilannetta voidaan tulkita Agnew'n (2002) tavoin yksilöllisten pyrkimysten ja yhteisöllisten tavoitteiden vuorotteluna. Lapset saattavat pyrkiä ensin toteuttamaan aikuisten toiveita, mutta päätyä lopulta muuttamaan toimintaansa vastaamaan paremmin omaa kokemustaan. Muutostilanteet ovat aina ristiriitaisia. Kanadalaisen, lapsena vuoroasuneita aikuisia tutkineen Denice Whiteheadin (2012, 53-54, 76) mukaan lapsi haluaa suojella sekä itseään että läheisiään emotionaalisilta takaiskuilta, joita esimerkiksi vuoroasumisesta luopuminen saattaisi nostaa esiin. Tämä on nähtävissä esimerkiksi Elinan (ath) kokemuksessa, jossa hän joutui kantamaan äidille aiheuttamansa surun taakkaa valitessaan isän luona asumisen.

H: Kun sä sit halusit sitä muutosta ja isälle kokonaan, miten sä sen asian hoisit?

Elina: Aika huonosti. Mä sanoin siitä isälle, et mä haluun tehdä tälleen ja isä sano, et jutellaan siitä vielä, et kerrot sit myöhemmin, kun isä oli tullu just hakemaan mua. Ja sit mä menin hakemaan mun tavaroita ja sanoin äidille, et mä oon ajatellu tällästä näin, sit äiti alko itkee ja siin tuli aika draama ja isäki tuli siihen puhumaan. Ja mä en muista, miten me sovittiin, et olinks mä vielä sen jälkeen, et tulin äidille viel viikoks tai jotain, mutta joo. Emmä ihan hirveen hyvin sitä hoitanu [hymähtää]. - -

H: Milt se sust tuntu?

Elina: Emmä tietenkään halunnu, et äiti tulis siitä surulliseks. Mä halusin, et meien välit, niiku äitikii on jälkikäteen sanonu sen jälkeen, et meien välit parani paljon sen jälkeen, kun me ei jouduttu asumaan samassa asunnossa.

$\mathrm{H}$ : Nii, et se oli tavallaan sit kuitenkin itseasiassa hyvä ratkasu. 
Elina: Nii, mut tietenki äidille raskasta silleen, ei varmaan kukaan haluu, et lapsi valitsee sen toisen vanhemman.

Kokemukset vuoroasumisen onnistumisesta tai epäonnistumisesta vaihtelivat myös sisarusten välillä.Vaikka konkreettiset tilanteet ja järjestelyt olivat samanlaiset, kokemus itselle oikeasta asumisvaihtoehdosta saattoi olla erilainen. Esimerkiksi Nean ja Nellan vanhemmilla oli huonot välit, mikä heijastui vahvasti myös tyttöjen elämään. Sisarusten tekemät ratkaisut oman asumisensa suhteen olivat kuitenkin erilaiset. Lapsena tehdyn haastattelun yhteydessä silloin 12-vuotias Nella suunnitteli lisäävänsä asumista isän luona mahdollisesti juuri niistä syistä, joita hän alla olevassa esimerkissä kuvaa. Aikuisena Nella kertoi päättäneensä pian ensimmäisen haastattelun ja kahdeksan vuoroasutun vuoden jälkeen muuttaa asumaan pelkästään äidille ja katkaisi silloin väliaikaisesti kokonaan suhteensa isään. Hän koki isän yrittäneen ostaa hänet asumaan luokseen.

Isä rankas mua siitä, etten muuttanu hänen luokseen ja sitte mun sisko, joka asu hänen luonaan sai tosi paljon kaikkea kivaa ja uutta, etelänmatkoja ja kaikkea. Meillä oli rahat tosi tiukassa äitin luona. Ja sit iskä ei meille antanu tai ostanu mitään, ja sit jos yhtään näytti et harmitti se, niin sieltä tuli aina sellanen piikki, et sit jos muutat tänne ni sieki saat. - - Mun mielest se oli epäreiluu ja on edelleenkin, miten meien iskä käytti sitä rahaa aseena tavallaan tai kiristyskeinona. Tällee kun mä jälkeenpäin mietin, se oli tosi törkeetä. (Nella ath)

Nellan sisko Nea puolestaan päätti 10-vuotiaana muuttaa asumaan äidin luota virallisesti isälle ja siirtyi käytän- nössä vuoroasumiseen, koska häntä säälitti jättää isää yksin. Nea vuoroasui aikuisikään ja itsenäiseen asumiseen siirtymiseen saakka. Toisin kuin Nella, hän ei kuitenkaan ollut kokenut tulleensa painostetuksi, vaikka päätyikin ratkaisuun siksi, ettei isä jäisi yksin. Nean (ath) kokemus paljastaa, miten lapsi ottaa päätöksissään huomioon omien toiveidensa lisäksi myös muut ihmiset (myös Agnew 2002).

Nea: Mä muistan, että mua säälitti iskä kauheesti, että mä olisin halunnu olla paljon enemmän äidin kanssa, mut sit jotenkin kävi sääliksi.

$\mathrm{H}$ : Muutiksä tavallaan niinku vähän sen takia sitten, et kun ne muut muutti pois [isän luota], ni sä muutit paikkaamaan? Nea:Joo. Se [äiti] sano, et jos mä haluun, se on ok, et minä saan itse päättää, missä minä haluun asua, mutta sit se oli huolissaan siitä, et isä on painostanu minua muuttamaan sinne, ettei sen tarvi olla yksin. Se halus varmistaa, ettei ole mistää semmosesta kyse. Se halus olla varma, et oikeesti haluun. Enkä silloin sanonu äitille, et mie muutan sen takia, et mie en halua, et iskä on yksin. (Nea ath).

Lapsen näkökulman ja toiveiden esiin saaminen vaatii lapsen kokemusten kuuntelemista, sillä lapselle voi olla hankalaa tuoda esiin syitä sille, miksi asumisjärjestely ei tunnu oikealta. Alla olevassa haastattelulainauksessa Kata (ath) kertoo, miten hänen vuoroasumisensa loppui kahden vuoden jälkeen 13-vuotiaana. Lapsena tehdyssä haastattelussa hän ei mainitse muutostoiveitaan, vaikka ensimmäinen haastattelu tehtiin vain vähän ennen vuoroasumisen loppumista. Tosin hän epäili silloin, ettei kumpikaan vanhemmista pitäisi mahdollisista muutosehdotuksista. On 
mahdollista, että Kata ei lapsena tehdyssä haastattelussa kokenut asumisjärjestelyjen muutosta mahdollisena siksi, että aikuiset eivät pitäisi siitä. Aikuisena Kata olisi toivonut lapsen näkökulman ja ajatusten syvällisempää kuuntelua ja yhteistä keskustelua sekä kokemusten pohjalla olevien syiden selvittelyä.

Kata: Sehän oli sillon, kun mie aloin, et mie en ois halunnu enää iskän luona asua, ni mie sain äitin kans tapella tosi kauan, et mie sain ylipääään munttaa vaan äitille. Kai se oli jollain taval sitä, et äiti ajatteli iskää, et se loukkais iskää tai... - -

$\mathrm{H}$ : Muistatko sellasia [tilanteita] millon olit erityisen onneton?

Kata: Niissä tilanteissa, kun mie iltasin itkin, et oisin halunnu äitin luokse ja sit mun piti vaan kestää ja olla siel iskällä, ne mie muistan oikein hyvin.

$\mathrm{H}$ : Sanoitko siitä isälle tai äidille, vai olikse niin, et sä pidit sisällä sen tuskan? Kata: Iskälle en sanonu, koska mie pelkäsin, et se sunttuu ja loukkaantuu siitä, mut äitille mie laitoin viestii tai soitin, et mie haluun tulla kotiin, nimenomaan tulla kotiin. Sitten aina, kun äiti sano, et kyl sie siel voit olla viel ja älä viitsi, ne on hyvin negatiivisii muistoja.

$\mathrm{H}$ : Näin jälkikäteen oisiksä toivonu, et äiti ois ottanu sun tunteet enemmän huomioon?

Kata: No joo, kyl mie toisaalta toivon, et ois kuunneltu enemmän minuu, mut sit taas toisaalta, kun jälkeenpäin ajattelee asiaa, kun on oma lapsi, ni mie oisin toivonu enemmän yhteistä keskustelua ja mun ajatuksien kuuntelua, että miksi mie haluun pois sieltä. Et puhutaan siitä, mikä siin on se syy, mikä mättää, eikä vaan, et koita jaksaa. (Kata ath)

Useimmat haastateltavat kokivat, että heidän muutosehdotuksiinsa oli suh- tauduttu myönteisesti ja ymmärtäväisesti. Erityisesti heillä oli ollut sananvaltaa siihen tahtiin, jolla kotia vaihdettiin. Lapsena tehdyissä haastatteluissa kaksi haastateltavaa kertoi oma-aloitteisesti pidentäneensä vaihtoväliä; aikuisena tehdyissä kolme muisteli tehneensä näin. Esimerkiksi Minna (lth) kertoi esittäneensä toiveen vaihtovälin pidentämisestä noin 15-vuotiaana puoliks $k y$ symyksen ja puoliks ilmoituksen muodossa.

Edellä olevia esimerkkejä voidaan tarkastella laajempana näkymänä siihen, ettei hyvien tai itselle parhaiden asumisratkaisuiden tekeminen aina ole yksiselitteistä. Ratkaisuissa on otettava huomioon paitsi oma kokemus oikein toimimisesta, myös valintojen merkitys muihin ihmisiin. Lapsena tehdyissä haastatteluissa lähes kaikki arvelivat asumisjärjestelynsä jatkuvan ennallaan, mutta 11 vuotta myöhemmin voidaan nähdä, miten moninaisiksi asumisjärjestelyt olivat muotoutuneet. Aiemmissa tutkimuksissa on esimerkiksi havaittu, että vuoroasuminen ei ole hyödyttänyt niitä, joilla oli erityisen lämmin äitisuhde, mutta huono suhde isään (Vanassche ym. 2013). Haastattelemiemme lasten kokemuksissa sama näkyi myös toisin päin: huono suhde äitiin vaikutti vuoroasumisen purkautumiseen.

Asumisjärjestelyissä on mukana paitsi aikuisten ja lasten väliset suhteet myös vanhempien keskinäinen suhde. Tämä näkyy esimerkiksi tilanteissa, joissa lapset toivat esille muutostarpeen, mutta vanhemmat halusivat ylläpitää nykyistä järjestelyä. Vanhemmat joutuivat ottamaan huomioon myös toistensa mielipiteet. Sovitusta ei haluttu lipsua ja saatettiin kokea myötätuntoa toista vanhempaa kohtaan tilanteissa, joissa 
lapsi halusi lopettaa tämän luona asumisen. Vähintään asiasta haluttiin ehtiä keskustella ja jättää kummallekin aikaa sopeutua tilanteeseen.

\section{LASTEN ASEMA ASUMISTA KOSKEVASSA PÄÄTÖKSENTEOSSA}

Suurimman osan kohdalla periaatteellisen päätöksen vuoroasumisesta olivat tehneet lasten vanhemmat. Sekä lapsena että aikuisena tehdyissä haastatteluissa kaikki haastateltavat olivat yksimielisiä siitä, että vuoroasuminen oli ollut vanhempien yhteinen päätös, josta ei ollut riidelty. Aikuisena tehdyissä haastatteluissa viisi haastateltavaa kertoi muistavansa, että heidän mielipidettään oli erityisesti kysytty. Lisäksi kaksi mainitsi, että olisi sen kertonut kysymättäkin, jos vanhempien päätös ei olisi miellyttänyt. Lapsena tehdyissä haastatteluissa puolet lapsista (10) kertoi, että he olivat olleet mukana päättämässä vuoroasumisesta, erityisesti sen vaihtorytmistä.

Päätöksenteon ristiriitaisuuteen liittyen Leena (ath) toi esille, ettei se ole aina helppoa: jos lapsi ei tiedä, missä se haluaa olla, ni onhan se hyödyllistä, et joku ottaa ohjat ja päättää.Toisaalta Miia (ath) nosti esille, että teinin mielipiteen huomiotta jättäminen aiheuttaa helposti riitoja. Murrosiässä haluttiinkin useimmiten lisätä asumista sen vanhemman luona, jolla oli vapaammat säännöt. Tilanteita väritti myös vanhempien suhtautuminen lapseen päätöksentekijänä; lasten toiveita saatettiin pitää aikuisen mielipidettä helpommin hetken mielijohteina, jotka unohtuisivat pian. Aina asian puheeksi ottaminen ei ollut lasten ensimmäinen keino osallistua päätöksentekoon, vaan lapset saattoivat tukeutua suoraan toimintaan, jossa jätettiin yksinkertaisesti menemättä toiselle vanhemmalle ennalta sovittuna aikana.

Joissain perheissä lapsilla oli vuoroasumiseen siirryttäessä valtaa päätöksentekoon ja asumisen järjestämisen käytäntöihin, mutta aikuiset muuttivat tilannetta myöhemmin koettuaan lasten omaehtoisen järjestelyn hankalaksi. Esimerkiksi Markus (ath) kertoi, miten hän ja hänen sisaruksensa saivat olla aluksi vapaasti kumman vanhemman luona tahansa. He vaihtoivatkin kotia tiheään muutaman päivän välein ja Markus hakeutui usein sinne, missä sisaret eivät olleet. Jonkin ajan kuluttua vanhemmat kuitenkin päättivät, että on parempi, että kaikki lapset ovat samassa paikassa viikon kerrallaan. Tämä ei rajoittanut heidän mahdollisuuttaan viettää aikaa molemmissa kodeissa, vaan ruokaviikko koski ainoastaan ruokailua ja nukkumista.

Mm, no... en osaa omalta kannalta sanoa kumpi oli parempi, mut fiksumpi tietysti oli se jälkimmäinen ratkasu että viikko viikko, käytännön kannalta paljon fiksumpi. Sekin ihan hyvä varmaan ollu, et me on samassa paikassa sisaruksetkin oltu sitten loppujen lopuks, että kuitenkin ollaan nykyisin tosi läheisiä siskojen kanssa, siitä on varmaan ollut tosi paljon hyötyä siinä. (Markus ath).

Markus ei lapsena pitänyt vanhempien tekemästä päätöksestä, koska oli ennen sitä saanut nauttia omasta rauhasta. Aikuisena hän ja hänen sisaruksensa kuitenkin näkivät muutoksessa positiivia seurauksia. He kokivat, että yhdessä asuminen oli lähentänyt heitä ja he olivat nyt toisilleen tärkeitä. Esimerkissä näkyy, miten monimutkaisesta tapahtumasta asumisjärjestelyssä on kyse; lapsen 
kokemus epämiellyttävästä muutoksesta saattaa jälkikäteen näyttäytyä oikeana ratkaisuna.

Millainen sitten pitäisi olla lapsen osuus asumista koskevassa päätöksenteossa eron jälkeen? Tähän ei varmasti ole olemassa yksiselitteistä vastausta. Lapsena tehdyssä haastattelussa kaikki olivat sitä mieltä, että lapsella pitää olla sananvaltaa asumista järjestettäessä ja hiukan alle puolet oli sitä mieltä, että lapsella on oikeus päättää asiasta itse: $K y l$ suurimmaks osaks [lapsen pitää saada päättää], mut kyl vanhemmatki päättää, jos ne haluu nähä lapsiinsa (Siru lth). Aikuisten haastatteluaineistossa näkemykset vaihtelivat ja niitä perusteltiin enemmän.

Sekä Aapo (ath) että Ville (lth) olivat sitä mieltä, ettei ole lapsen tehtävä päättää asiasta. Samalla he kuitenkin korostivat, että ellei ole jotain erityistä syytä tehdä toisin, eron jälkeisen asumisen lähtökohta pitäisi olla vuoroasuminen. Vaikka Elina (ath) oli päättänyt 12-vuotiaana muuttaa vain isälle, hän piti hyvänä, että vanhemmat olivat aikoinaan päätyneet vuoroasumiseen: $K y l$ tietenki se oli hyvä, et mä asuin myös äidin kanssa, koska muuten vois olla vähän sillee etäisempi äitiin, kun mitä on. Siinä sai ne lapsuusvuodet kuitenkin kummaltakin vanhemmalta, saada kasvatuksen. 12 vuoden ikä nousi myös esille haastatteluissa. Kahdelle haastateltavalle oli selvää, että silloin oma vaikutusvalta itseä koskevissa asioissa kasvaa. Elina oli käyttänyt tietoa omaksi hyväkseen, mutta Nellan tapauksessa päätäntävallan kasvu oli aiheuttanut hänelle hankaluuksia: Kun mie olin täyttämässä 12, kovasti painostettiin muuttamaan iskälle (Nella ath).
Myös aikuisina tehdyissä haastatteluissa puolet haastatelluista oli sitä mieltä, että lapsen tai nuoren tulisi saada päättää asumisestaan itse. Lisäksi esimerkiksi Jaakko (ath) piti tärkeänä, että aikuiset hyväksyisivät lapsen päätöksen. Hän ehdotti käytännöllisenä ratkaisuna asumiseen koeaikaa, jotta vanhemmat uskaltaisivat paremmin kokeilla vuoroasumista ja siten mahdollisesti huomata sen toimivuuden.

Moni oli sitä mieltä, että määrättyyn ikään asti aikuiset päättävät, mutta lapsen mielipidettä on hyvä kuulla. Aikuisena tehdyssä haastatteluaineistossa käsitys sopivasta iästä vaihteli viidestä viiteentoista, ja keskiarvona sopivana ikänä päätöksentekoon osallistumiselle pidettiin noin 10 ikävuotta. Lapsena tehdyissä haastatteluissa päädyttiin tähän samaan keskiarvoon. Toisin sanoen, ikä tai asian ajankohtaisuus ei muuttanut haastateltavien käsitystä asiasta. Molemmilla haastattelukerroilla oltiin usein sitä mieltä, että oikea ikä tehdä päätöksiä oli sama, kuin minkä ikäisinä haastateltavat olivat itse niitä tehneet. Kaikki aikuiset haastatellut eivät maininneet tarkkaa ikää, vaan nostivat esille myös lapsen henkilökohtaiset ominaisuudet ja kypsyyden. Kolmen aikuisen haastateltavan mielestä vanhempien päätöksenteko on perusteltua siksi, että lapsi ei pysty ottamaan huomioon kaikkia asiaan vaikuttavia seikkoja (ks. Warshak 2003).

15-16 [on hyvä ikä päättää], ni ehkä siinä kohtaa pystyy jo hahmottamaan sitä, ei tuu sellasta, tuol on isompi telkkari ja tuolla on, nää suostuu ajattaa kaikkialle ja täallä joutuu menee bussilla ja polkupyörällä satoi tai paistoi, sellasta. Ehkä ittelläni, 
pienempänä, olisin tehny ehkä just sellasia pä̈töksiä, niitten perusteella. (Toni ath)

Joka kolmannessa aikuisten haastattelussa tuli esille, että vuoroasumista ei pidä toteuttaa vastoin lapsen tahtoa. Lapsen tahdon selvittäminen on oleellista myös siksi, että lasten kokemukset ovat henkilökohtaisia, ja esimerkiksi sisaruksilla voi olla erilaisia mielipiteitä ja toiveita, joita pitää kunnioittaa yksilöllisesti. Samaan aikaan päätöksenteon tulisi kiinnittyä yhteiseen keskusteluun, jolloin päätös ei jää vain lapsen tehtäväksi.

Mieki oon miettiny sitä, et meien iskä ei ollu ihan parhaas kunnos silloin, kun myö eniten siel käytiin ja meien vanhemmathan oli oikeudessa monta kertaa ja iskäl oli lähestymiskielto äitille, meien iskä joi tosi paljon ja oli aika agressiivinen ja semmonen, puhui meille tosi kauheita juttuja, vaik me oltiin lapsii. Mie halusin sillo olla isän luona, mut silti toivon, et se [isän tilanne] ois otettu jotenkin huomioon siinä. Miten se sit ois ollu mahollista, koska halusin olla siellä isän luona. Mut jos näyttää siltä, et toinen vanhempi ei vaikka pysty olemaan sen lapsen kanssa kahestaan tai pidempiä aikoja, ni sitte se on hyvä, että joku punttuu siihen, reaaliaikasesti. [naurahdus] (Nella ath)

Nella kertoo esimerkissä tilanteesta, jossa muiden aikuisten olisi hänen mielestään pitänyt arvioida vanhemman kykyä huolehtia lapsistaan, vaikka Nella itse halusikin vielä tässä kohtaa asua isän luona. Kaiken kaikkiaan aikuiset haastateltavat pitivät vuoroasumisen ehdottomana edellytyksenä sitä, että kumpikin vanhempi pystyy takaamaan lapselle turvallisen kodin. Esimerkiksi toisen vanhemman psyykkisen hyvinvoinnin horjuessa lapsen voi olla vaikea tehdä päätöksiä, joten aikuisten on tehtävä ne hänen puolestaan.

Käytännön tasolla haastateltavat neuvoivat sekä aikuisina että lapsina vuoroasuvaa lasta puhumaan rohkeasti vanhemmille omista tuntemuksista ja toiveista. Erityisesti aikuiset haastateltavat antoivat vanhemmille ohjeeksi aika ajoin kysellä lapselta, mitä hänelle kuuluu ja mitä hän toivoo.

\section{PohdintaA}

Vuoroasuminen näyttäytyy aineistomme valossa järjestelynä, joka syntyy kaikkien osapuolten yhteisestä tarpeesta järjestää eron jälkeinen asuminen parhaalla mahdollisella tavalla. Neuvotteluja lasten kanssa käytiin paitsi vuoroasumiseen siirtymisestä ylipäänsä, myös sen aikana liittyen esimerkiksi asumisen uudelleenjärjestämiseen tai vuoroasumisen lopettamiseen. Tunnistettuja syitä uusille neuvotteluille olivat esimerkiksi ihmissuhteisiin liittyvät syyt sekä käytännön elämisen järjestämiseen liittyvät syyt, kuten oman huoneen puuttuminen tai kotien erilaiset säännöt.

Tarkasteltaessa lapsuuden vuoroasumiskokemuksia aikuisuudesta käsin näyttäytyy vuoroasuminen asumismuodolta muiden joukossa ja sen jatkumisesta voidaan neuvotella tarvittaessa uudelleen. Agnew'n (2002) ajatteluun tukeutuen aikuisuudesta käsin lapsuuden kokemukset tulevat kerrotuiksi suhteessa muistoihin lapsuuden yhteisöistä sekä toisaalta suhteessa siihen tilanteeseen, jossa niitä kerrotaan. Lapsuuden kokemukset muokkautuvat ja niihin alkaa liittyä näkökulmia,joita lapsena ei tullut tunnistaneeksi. Tästä huolimatta aikuisina kerrotuista kokemuksista voi- 
daan hahmottaa lasten tarpeita: millä tavoin olisin toivonut olevani mukana asumista koskevassa päätöksenteossa? Lasten kokemusten perusteella molempien vanhempien kanssa asuminen on tärkeää, jotta kumpaakin on mahdollista tavata riittävästi. Nuorten kohdalla vanhemman kanssa samassa kodissa asuminen ei enää samalla lailla takaa toimivia suhteita, vaan heidän välinsä vanhempiin voivat jopa parantua erillään asuttaessa.

Vuoroasumisen tasapuolisuudesta puhuttaessa oleellista ei ole ajan jakaminen tasan kotien välillä, vaan saada järjestely vastaamaan mahdollisimman hyvin lapsen tarpeita. Lapsen ihmissuhteiden ja toiveiden mukainen asumisjärjestely on yhteydessä lapsen hyvinvointiin. (Kaltenborn 2001.) Tässä joudutaan kuitenkin käymään jatkuvasti rajanvetoa lasten toimijuuden ja suojelun yhdistämisestä. Kuten esimerkiksi Nean ja Nellan tai Markuksen kokemukset osaltaan näyttävät, tilanteet ovat erilaisia ja vaativat pohtimaan, milloin on oleellista huomioida lasten näkökulma ja milloin on tarkoituksenmukaista päättää asumisesta ohi lapsen toiveiden. Lisäksi haastateltujen kokemusten pohjalta voidaan sanoa, ettei muutos tai vuoroasumisen päättyminen ole merkki järjestelyn epäonnistumisesta tai onnistumisesta, vaan vertautuu muihin asumiseen liittyviin muutoksiin.

Aineistomme valossa on kaiken kaikkiaan keskeistä tarkastella sitä, millaiset perustelut ja tulkinnat päätösten taustalla vaikuttavat. Lasten päätöksenteon taustalla voi olla monen tasoisia perusteita aina tavaroista vapauksiin ja emotionaalisiin syihin. Esimerkiksi sääntöjen erilaisuuden vuoksi toisen vanhemman luokse muuttaminen voidaan tulkita oman edun tavoitteluksi. Aikuisen näkökulmasta peruste voi vaikuttaa merkityksettömältä, mutta lapsi kokee tätä kautta voivansa vaikuttaa itseään koskevaan päätöksentekoon. Perustelujen epämääräisyys voi johtua myös siitä, ettei lapsi halua tai koe pystyvänsä kertomaan kaikkia todellisia perusteitaan. Näissä tilanteissa lapset saattavatkin asettaa vanhempien tarpeet omien tarpeidensa edelle (myös Haugen 2010; Whitehead 2012). Haastatellut kuvasivat monin tavoin, kuinka he pyrkivät ottamaan samaan aikaan huomioon omat tarpeensa ja yhdistämään ne vanhempien ja sisarusten tarpeisiin. Lasten ratkaisuissa on samaan aikaan läsnä sekä heidän omat toiveensa ja tarpeensa että heidän tulkintansa yhteisön muiden jäsenten toiveista ja tarpeista (Agnew 2002).

Lapsella on oltava todellinen mahdollisuus vaikuttaa, mutta samalla on ymmärrettävä lapsen erityinen asema päätöksenteon prosesseissa. Kuuntelun ja neuvottelumahdollisuuksien olemassaolon ei tulisi tarkoittaa lasten vastuuttamista tehdyistä valinnoista, vaan ymmärrystä lasten kokemusten merkityksestä sekä heidän mielipiteensä kuuntelemista ja huomioon ottamista (Stenvall 2018). Kuten haastateltavien kokemuksista tuli näkyviin, lapset ovat valmiita tuomaan esiin mielipiteensä ja toivovat vanhemmiltaan avointa keskustelua (myös Berman 2018).

Vuoroasumista ollaan linjaamassa virallisesti ja lapsenhuoltolakiin ehdotetaan muutoksia, joilla voidaan vahvistaa lapsen oikeutta osallistua ja tulla kuulluksi häntä koskevissa asioissa (Oikeusministeriö 2017). Käytännössä kuulemisen 
järjestäminen on monimuotoisempaa lähtien siitä, kenen tulisi kuulla lasta asumisjärjestelystä sovittaessa. Mikäli vanhemmat päättävät lapsen asumisesta eron jälkeen ilman ammattilaisten apua, jää lasten näkemysten huomioiminen automaattisesti heidän vastuulleen. Lapsen näkökulman huomioon ottamisen tavoitteena on välttyä tilanteilta, joissa lapsi ei pysty kertomaan omia toiveitaan asumisestaan sekä toisaalta niiltä tilanteilta, joissa lapselle annetaan liikaa vastuuta asumisesta päättämisessä. Vuoroasuminen voi olla lapsen kannalta paras eron jälkeinen asumismuoto, mikäli järjestely on lapsikeskeinen ja lapsen mielipiteitä kuullaan ja kunnioitetaan (esim. Haugen 2010); toisaalta se voi olla huonoin, jos sitä toteutetaan vastoin lapsen tahtoa. Lasten tarpeet ja kokemukset voivat samankin perheen sisällä olla erilaiset. Tämä paljastaa, miten monimutkaisesta kokonaisuudesta on kyse: vuoroasumisen onnistuminen ei ole kiinni vain vanhempien tahdosta ja otollisista olosuhteista, vaan myös jokaisen lapsen yksilöllisistä ominaisuuksista, kokemuksista ja halusta vuoroasua. Vanhempien olisi pystyttävä ottamaan huomioon ja sovittamaan käytäntöön lasten keskenään erilaiset ja ajan myötä muuttuvat tarpeet.

Kaiken kaikkiaan lapsuuden vuoroasuminen muistettiin lähtökohtaisesti hyvänä vaihtoehtona, jota pystyttiin aikuisuudesta käsin arvioimaan myös kriittisesti; aikuiset haastateltavat pystyivät kertomaan aiempaa avoimemmin muun muassa asumisjärjestelyihin liittyvistä ihmissuhdeongelmista ja näkemään ratkaisuissa myös negatiivisia sävyjä (myös Campo ym. 2012; Whitehead 2012, 42). Esitetystä kritiikistä huolimatta vuoroasumista pidettiin hyvänä vaihtoehtona eron jälkeiseen asumiseen: yhtä lukuun ottamatta kaikki olisivat valinneet sen myös omalle lapselleen. Monimutkaisuudestaan huolimatta vuoroasuminen näyttäytyy haastateltujen mielestä parhaana eron jälkeisenä asumismuotona, mutta vain sillä edellytyksellä, että lapsi on mukana siitä päättämässä.

\section{KiRJallisuUs}

Agnew, John (2002) Place and politics in modern Italy. Chicago: The university of Chicago press.

Alanen, Leena \& Karila, Kirsti (2009) Lapsuus, lapsuuden instituutiot ja lasten toiminta. Tallinna:Vastapaino.

Autonen-Vaaraniemi, Leena \& Forsberg, Hannele (2015) Vuoroasuminen lapsuuden paikkakokemuksina kolmen tyyppitarinan valossa. Yhteiskuntapolitiikka 80 (5), 447-456.

Bergström, Malin \& Modin, Bitte \& Fransson, Emma \& Rajmil, Luis \& Berlin, Marie \& Gustafsson, Per A. \& Hjern, Anders (2013) Living in two homes -a Swedish national survey of wellbeing in 12 and 15 year olds with joint physical custody. BMC Public Health 13. https://doi. org/10.1186/1471-2458-13-868

Berman, Rakel (2018) Children's influence on dual residence arrangements: Exploring decision-making practices. Children and Youth Services Review 91, 105-114. https://doi.org/10.1016/j. childyouth.2018.05.038

Campo, Monica \& Fehlberg, Belinda \& Millward, Christine \& Carson, Rachel (2012) Shared parenting time in Australia: Exploring children's views. Journal of Social Welfare and Family Law 34 (3), 295-313. https://doi.org/10.1080/0964 9069.2012.750480

Carlsund, Åsa \& Eriksson, Ulrika \& Löfstedt, Petra, \& Sellström, Eva (2012) Risk behavior in Swedish adolescents: Is shared physical custody a risk or a protective factor? European Journal of Public Health, 23 (1), 3-8. https://doi. 
org/10.1093/eurpub/cks011

Cashmore, Judy \& Parkinson, Patrick \& Weston, Ruth \& Patulny, Roger \& Redmond, Gerry \& Qu, Lixia \& Baxter, Jennifer \& Rajkovic, Marianne \& Sitek, Tomasz \& Katz, Ilan (2010) Shared care parenting arrangements since the 2006 family law reforms: Report for: Australian Government AttorneyGeneral's Department. Sydney: Social Policy Research Centre, University of New South Wales. https://www.ag.gov. au/FamiliesAndMarriage/Families/ FamilyLawSystem/Documents/SharedCareParentingArrangementssincethe2006FamilyLawreformsreport.PDF Luettu 9.9.2016.

Demografiska rapporter (2014) Olika familjer lever på olika sätt. Om barns boende och försörjning efter en separation. Stockholm: Statistiska centralbyrån.

Fabricius, William \& Hall, Jeffrey (2000) Young adults' percpectives on divorce. Living arrangements. Family and Conciliation Courts Review 38 (4), 446-461. https:// doi.org/10.1111/j.174-1617.2000. tb00584.x

Forsberg, Hannele \& Ritala-Koskinen, Aino \& Autonen-Vaaraniemi, Leena \& Kauko, Outi (2014) Lasten monipaikkainen asuminen sosiaalisena ilmiönä ja hyvinvoinnin kysymyksenä. Hyvinvointikatsaus 25 (1), 29-35.

Forss, Anne \& Säkkinen, Salla (2018) Lapsen elatus ja huolto sekä isyyden selvittäminen 2017. Tilastoraportti 18/2018. Helsinki: Terveyden ja hyvinvoinnin laitos. http://www.julkari.fi/bitstream/ handle/10024/136402/Tr18_18. pdf? sequence $=3 \&$ isAllowed $=\mathrm{y} \quad$ Luettu 31.8.2018.

Fransson, Emma \& Bergström, Malin \& Hjern, Anders (2015) Barn i växelvis boende - en forskningsöversikt. Rapport från CHESS. Stockholm: Stockholms universitet. http://www.chess.su.se/ polopoly_fs/1.261599.1450340833!/ menu/standard/file/Barn\% $20 \mathrm{i} \% 20$ va\%CC $\% 88$ xelvis $\% 20$ boende $\% 20-\% 20$ en $\% 20$ forskningso $\% \mathrm{CC} \% 88$ versikt.pdf Luettu 4.10.2016.

Eskola, Jari \& Suoranta, Juha (1998) Johdatus laadulliseen tutkimukseen. Tampere: Vastapaino.
Giorgi, Amadeo (1997) The theory, practice, and evaluation of the phenomenological method as a qualitative research procedure. Journal of Phenomenological Psychology 28 (2), 235-261. https://doi. org/10.1163/156916297X00103

Haugen, Gry Mette (2010) Children's perspectives on everyday experiences of shared residence: time, emotions and agency dilemmas. Children \& Society 24 (2), 112-122. https://doi.org/10.1111/ j.1099-0860.2008.00198.x

Henwood, Karen \& Fiona Shirani (2012) Timescapes Methods Guides Series 2012 Guide No. 4 Extending Temporal Horizons. http://www.timescapes. leeds.ac.uk/assets/files/methods-guides/ timescapes-henwood-extending-temporal-horizons.pdf. Luettu 29.9.2017.

Kallio, Kirsi Pauliina \& Häkli, Jouni (2010) Are there politics in childhood? Space and Polity 15 (1), 21-34.

Kaltenborn, Karl-Franz (2001) A Children's and young people's experiences in various residential arrangements: a longitudinal study to evaluate criteria for custody and residence decision making. British Journal on Social Work 31 (1), 81-117. https://doi.org/10.1093/ bjsw/31.1.81

Keskinen, Vesa \& Högnabba, Stina (2014) Kahden kodin lapset - "kummankin kaa”. Helsinki: Helsingin kaupungin tietokeskus.

Laine, Timo (2001) Miten kokemusta voidaan tutkia? Fenomenologinen näkökulma. Teoksessa Juhani Aaltola \& Raine Valli (toim.) Ikkunoita tutkimusmetodeihin II. Jyväskylä: PS-kustannus, 26-43.

Lamb, Michael E. \& Kelly, Joan B. (2009) Improving the quality of parent-child contact in separating families with infants and young children: empirical research foundations. Teoksessa Robert M. Galazter-Levy \& Louis Kraus \& Jeanne Galatzer-Levy (toim.) The scientific basis of child custody decisions (2. painos). Hoboken, NJ:Wiley, 187-214.

Linnavuori, Hannariikka (2007) Lasten kokemuksia vuoroasumisesta. Jyväskylä studies in education, psychology and social research 313. Jyväskylä: Jyväskylän yliopisto.

Lodge, Jodie, \& Alexander, Michael (2010) 
Views of adolescents in separated families. Sydney: Australian Institute of Family Studies. http://citeseerx.ist.psu. $\mathrm{edu} / \mathrm{viewdoc} /$ download?doi=10.1.1.6 $51.7173 \&$ rep $=$ rep $1 \&$ type $=p d f \quad$ Luettu 29.8.2016.

McIntosh, Jennifer \& Smyth, Bruce \& Kelaher, Margaret \& Wells, Yvonne \& Long, Caroline. (2010) Post separation parenting arrangements: Outcomes for infants and children. Sydney: Australian Government. https://aifs.gov.au/publications/family-matters/issue-86/postseparation-parenting-arrangements $\mathrm{Lu}-$ ettu 7.9.2016.

Myllyniemi, Sami (2015) Arjen jäljillä. Nuorisobarometri 2015. Helsinki: Nuorisotutkimusverkosto.

Nielsen, Linda (2014) Shared physical custody: summary of 40 studies on outcomes for children. Journal of Divorce \& Remarriage 55 (8), 613-635. https:// doi.org/10.1080/15379418.2017.1422 414

Nielsen, Linda (2018) Joint versus sole physical custody: Outcomes for children independent of family income or parental conflict. Journal of Child Custody 15 (1), 1-20.

Nikander, Pirjo (2014) Laadullinen pitkittäistutkimus ja terveys. Sosiaalilääketieteellinen aikakauslehti 51 (4), 243-252.

Oikeusministeriö (2017) Lapsenhuoltolain uudistaminen. Työryhmän mietintö. Oikeusministeriön lausuntoja 47/2017. Helsinki.

Panttila, Raija (2005) Kahden kodin lapsuus. Katsaus lapsen vuorottelevan asumisen kirjallisuuteen ja käytännön toteutukseen. SOCCAn ja Heikki Waris -instituutti. Helsinki. http://www.socca. fi/files/77/Kahden_kodin_lapsuus.pdf Luettu 28.3.2018.

Parkinson, Patrick \& Cashmore, Judy \& Single, Judi (2005) Adolescents' views on the fairness of parenting and financial arrangements after separation. Family Court Review 43 (3), 429-444. https://doi.org/10.1111/j.17441617.2005.00044.x

Perttula, Juha (2000) Kokemuksesta tiedoksi: fenomenologisen metodin uudelleen muotoilua. Kasvatus 31 (5), 428-442.

Rissanen, Antti (2016) Perhemuodon yh- teys nuorten hyvinvointiin ja riskikäyttäytymiseen. Erityistarkkailussa vuoroasuminen. Yhteiskuntapolitiikka 81 (3), 247-258.

Rissanen, Antti \& Kääriäinen, Aino \& Rantala, Kati \& Sarasoja, Laura \& Aikio, Marjut (2017) Vuoroasumisen periaatteet ja sopiminen vanhempien ja viranomaisten käsityksinä. Janus 25 (1), 38-56.

Sarasoja, Laura \& Rantala, Kati (2015) Ero lapsiperheessä: Elatus, sopiminen ja vuoroasuminen. Helsinki: Helsingin yliopisto, valtiotieteellinen tiedekunta. Kriminologian ja oikeuspolitiikan instituutti.

Singer, Anna (2008) Active parenting or Solomon's justice? Alternating residence in Sweden for children with separated parents. Utrecht Law Review 4 (2), 3547. https://doi.org/10.18352/ulr.64

Smith Anne B. \& Taylor, Nicola J. \& Tapp, Pauline (2003) Rethinking children's involvement in decision-making after parental separation. Childhood 10 (2), 201-216. https://doi. org/10.1177/0907568203010002006

Sodermans, An Katrien \& Matthijs, Koen \& Swicegood, Grey (2013) Characteristics of joint physical custody families in Flanders. Demographic Research 28 (29), 821-848. https://doi.org/10.4054/ DemRes.2013.28.29

Socialstyresen (2004) Växelvis boende. Att bo hos bode pappa och mamma fast de inte bor tillsammans -Reviderad verson 2004. http://www.stromsund.se/download/ 18.3b063add1101207dd46800027577/ V\%C3\%A4xelvis+boende.pdf Luettu 27.3.2018.

Stenvall, Elina (2009) "Sellast ihan tavallist arkee".Helsinkiläisten3-6.-luokkalaistenarkija ajankäyttö. Helsinki: Helsingin kaupungin tietokeskus.

Stenvall, Elina (2018) Yhteiskunnallinen osallisuus ja toimijuus. Lasten osallistuminen, kansalaisuus ja poliittisuus arjen käytäntöinä. Akateeminen väitöskirja. Tampere: Acta Universitatis Tamperensis 2407.

Tuomi, Jouni \& Sarajärvi, Anneli (2002) Laadullinen tutkimus ja sisällönanalyysi. Helsinki:Tammi.

Turunen, Jani (2016) Shared physical custody and children's experiences of stress. Stockholm Research Reports in De- 
mography 2016:8. Stockholm: Stockholm University.

Vanassche, Sofie \& Sodermans, An Katrien \& Matthijs, Koen \& Swicegood, Gray (2013) Commuting between two parental households: the association between joint physical custody and adolescent wellbeing following divorce. Journal of family Studies 19 (2), 139-158. https:// doi.org/10.5172/jfs.2013.19.2.139

Warshak, Richard A. (2003) Payoffs and pitfalls of listening to children. Family Relations 52 (4), 378-384. https://doi. org/10.1111/j.1741-3729.2003.00373.x

Whitehead, Denice (2012) The shared custody experience: the adult child's perspective on transitions, relationships and fairness. Academic dissertation. On-
tario:The University of Guelph. https:// atrium.lib.uoguelph.ca:8443/xmlui/bitstream/handle/10214/3595/Final\%20 Whitehead\%20Dissertation\%205-8-12. pdf Luettu 6.4.2017.

Yleissopimus lapsen oikeuksista (1989) Yhdistyneet Kansakunnat. https://www. unicef.fi/lapsen-oikeudet/sopimus-kokonaisuudessaan/ Luettu 26.3.2018.

Öberg, Gunnar \& Öberg, Bente (1985)

Den delade familjen. Samtal med 60 familjer om gemensam vårdnad. Forskningrapport från pedagogiska institutionen. Stockholm: Stockholm universitet.

Öberg, Gunnar \& Öberg, Bente (2002) Vuxna skilsmässöbarn berättar. Stockholm: Prisma. 